\title{
An Enhanced Result Processing and Checking System for Public Universities using 2FA and TOTP
}

\author{
${ }^{1}$ Okechukwu O. Anyiam \\ Department of Information Technology \\ National Open University of Nigeria, \\ Abuja, Nigeria
}

\author{
${ }^{2}$ Francisca N. Anyiam \\ Department of Information Technology \\ Federal University of Technology Owerri, \\ Imo, Nigeria
}

\author{
${ }^{3}$ Ugochi A. Okengwu \\ Department of Computer Science \\ University of Port Harcourt, Rivers,
}

Nigeria

\begin{abstract}
Various universities in developing countries have made several attempts to develop reliable solution that will centrally process student's result and convey same to these students in a seamless manner. There have been several complaints from students on issues bordering on missing scores, wrong computations, secured access to scores and results. We explored the result processing and checking challenges presently faced by public universities in Nigeria, and implemented an enhanced online system of students' result processing and result checking, which combated these challenges. Microsoft ASP.Net, JavaScript, XML, Java, HTML, CSS, JSON, JQuery, Web-API and Android technologies were used for this implementation. This method provides unambiguous identification of users by using two-factor authentication - username/password and timebased one-time password. Enhanced online result processing and checking system provides a platform for easy course registration by students, result collation, grading and publishing by lecturers, result checking by students and management decisions by school authorities alongside Exams department. An evaluation of the new enhanced online system proved that it is more efficient than the existing system. The new enhanced online result processing and checking system has higher quality of information $(92 \%)$, speed of access $(93 \%)$, secured $(91 \%)$, ease of use $(92.5 \%)$ and low consumption of time $(2 \%)$. The financial analysis yielded a positive net present value (NPV) and a very impressive return on investment (ROI).
\end{abstract}

Keywords-2FA, TOTP, ROI, NPV

\section{INTRODUCTION}

While the impact of web or online result processing and checking system is appreciated, the advent of mobile communication technology has changed the face of Information Technology (IT). "Mobile technologies are becoming more embedded, ubiquitous and networked with enhanced capabilities for rich social interactions, context awareness and internet connectivity" [1]. Mobile phones are highly effective means of disseminating information to students since they have it and take it almost everywhere they go. According to a survey carried out by Pistilli and Bowen (2012) using 3900 Purdue University students, showed that $68 \%$ prefers mobile apps because they are faster while $70 \%$ are of the opinion that mobile apps are easier to use when compared to a web platform.
In this work, we combined the use of web-based system and advantages offered by mobile applications in addressing the problems of result processing and result checking in public universities. It tends to bring course registration and result checking to the doorsteps of students and as well make result processing and publishing easier for lecturers and staff of Records department. Due to the sensitivity of students results, we added a second authentication layer that uses time-based one-time password (TOTP). The TOTP is sent to users via SMS.

\section{RELATED WORKS}

[2] studied the "inadequacies involved in the manual method of compiling students' result in secondary schools in Nigeria". They critically examined the methods of result processing and checking in in some secondary schools. They identified the problems and proposed a new system which combatted some of the problems. [3] observed that the number of applicants seeking admission into Nigerian Universities, every year increases by leaps and bounds although the Universities lack the commensurate facilities to meet the challenges of admitting the high number of applicants. She reasoned that this has made the admission officers have to manually evaluate every candidate's data against the set admission requirements to screen the applicants in order to select the number of candidates that their universities can accommodate.

[4] highlighted that the "end-of-course grades assigned by lecturers are intended to convey the level of achievement of each student in the class". There is need to use an efficient method in carrying out these grading. Except this is done, a lot of wrong decisions will be made. They agreed with [3] that "the processing of results is found to be rather tedious, especially when carried out manually, and when the number of students is large". Manual processes take a lot of time and has greater chances of leading decision makers astray. The use of computers has eased these processes and has helped turning out more accurate reports.

[5] used the structured system analysis and design methodology in designing and implementing an integrated result processing system in a networked environment. Many 
reviews on result processing show that majority of universities in developing countries still process and check their results manually. They are slow in adapting to new technologies because of infrastructures and maintenance. [6] adopted the cloud computing model in its proposed student result computation system design. He solved the afore-mentioned problems of high cost of infrastructure. His model offered a novel framework for student result computation as a cloud computing service.

This work provides a web and mobile-based portal that improved on the security lapses discovered in the way results are presently being managed in public institutions of developing countries like Nigeria. The enhanced system provides an easy-to-use portal that is reachable and easily accessible to students, lecturers and management staff and is more secured. It makes result collation, processing, approval, publishing and checking easy.

\section{METHODOLOGY}

\section{A. Population of Study and Data Collection Instrument}

We choose these two Universities in Nigeria, namely, National Open University of Nigeria (NOUN) and Federal University of Technology Owerri (FUTO), because of their renowned performance in the academic industry and the quality of graduates they have produced in the society. Whereas, NOUN has its result processing and checking system computerized, though with so many challenges, FUTO runs a totally manual system.

The data collection instruments used were questionnaire, interview method, electronic/online methods and observation/examination of documents. This study adopted the Delphi method (questionnaire-based data quality methodology) in data collection. The Delphi method is used for the elicitation of opinions of experts [7]. These experts (academic and non-academic staff in different fields) which are divided into categories such as the Information Professionals (IPs), Information Consumers (ICs), and the Independent Experts (IEs) answered questionnaires from which we provided a summary of the experts' forecasts in tables.

\section{B. Sampling Design and Procedure}

The sampling design employed in this work is stratified sampling which is a variant of random sampling. The first group that was reached by the researcher was lecturers or academic staff which are estimated to be 500. For a $95 \%$ confidence level (5\% significance interval) a sample size of 200 was arrived at. The second group, non-academic staff (ie Exams and Records Department staff), were estimated to be about 30 and a sample size of 27 was derived. The performance Indicators used for both the Existing and proposed Systems are time consumption, security, ease of use, speed of access and quality of information.

\section{Analysis of Data Collected from the Existing System}

This study adopted the Delphi method (questionnairebased data quality methodology) in data collection and standard benchmark for evaluation of the existing and proposed system. (IPs)

1) Assessment/Measurement: Information Professionals

A total of 45 copies of questionnaire were collected from people identified in this role. The Table I shows the control matrix of the data collected in this role.

\section{TABLE I. CONTROL MATRIX FOR INFORMATION PROFESSIONALS}

\begin{tabular}{|l|c|c|c|c|c|c|}
\hline \multicolumn{1}{|c|}{$\begin{array}{c}\text { Likert } \\
\text { Scale }\end{array}$} & $\begin{array}{c}\text { Extremely } \\
\text { Low }\end{array}$ & Low & Neutral & High & $\begin{array}{c}\text { Very } \\
\text { High }\end{array}$ & Rank \\
\cline { 2 - 8 } $\begin{array}{l}\text { Performance } \\
\text { Indicator }\end{array}$ & 1 & 2 & 3 & 4 & 5 & \\
\hline Time Consumption & 0 & 3 & 5 & 27 & 10 & 2 \\
\hline Security & 4 & 32 & 0 & 9 & 0 & 1 \\
\hline Ease of Use & 17 & 20 & 4 & 4 & 0 & 1 \\
\hline Speed of Access & 10 & 25 & 2 & 0 & 1 & 2 \\
\hline $\begin{array}{l}\text { Quality of } \\
\text { information }\end{array}$ & 16 & 20 & 4 & 3 & 2 & 2 \\
\hline
\end{tabular}

From Table I, the number of respondents in this category that classified the current system as low, extremely low in terms of security, ease of use, speed of access, quality of information and high, very high in time consumption are 36, $37,35,36$ and 37 respectively which corresponds to category of users $80 \%, 82.2 \%, 77.7 \%, 80 \%$ and $82.2 \%$ of the total respondents in this category. Hence, according to this category of users, this satisfies the idea that the current system is weak in these areas.

\section{2) Assessment/Measurement: Information Consumers} (ICs)

A total number of 89 copies of questionnaire were collected from people identified in this role. The Table II shows the control matrix for Information consumers.

TABLE II. CONTROL MATRIX FOR INFORMATION CONSUMERS

\begin{tabular}{|c|c|c|c|c|c|c|}
\hline $\begin{array}{l}\text { Likert } \\
\text { Scale }\end{array}$ & $\begin{array}{c}\text { Extremely } \\
\text { Low }\end{array}$ & Low & Neutral & High & Very High & Rank \\
\hline $\begin{array}{l}\text { Performance } \\
\text { Indicator }\end{array}$ & 1 & 2 & 3 & 4 & 5 & \\
\hline Time Consumption & 0 & 3 & 7 & 39 & 40 & 2 \\
\hline Security & 33 & 49 & 7 & 0 & 0 & 1 \\
\hline Ease of Use & 20 & 57 & 4 & 7 & 1 & 1 \\
\hline Speed of Access & 30 & 50 & 7 & 2 & 0 & 2 \\
\hline $\begin{array}{l}\text { Quality of } \\
\text { Information }\end{array}$ & 31 & 47 & 5 & 6 & 0 & 2 \\
\hline
\end{tabular}

From Table II, the number of respondents in this category that classified the current system as low and extremely low in terms of security, ease of use, speed of access, quality of information and high, very high in time consumption are 82 , $77,80,78$ and 79 respectively which corresponds to category of users $92 \%, 86.5 \%, 89.8 \%, 87.6 \%$ and $88.8 \%$ of the total respondents in this category. Hence, according to this category of users, this satisfies the idea that the current system is weak in these areas.

3) Assessment/Measurement: Independent Experts (lEs)

A total number of 66 copies of questionnaire were collected from people identified in this role. The Table III shows the control matrix of the data collected in this role. 
TABLE III. CONTROL MATRIX FOR INDEPENDENT

\begin{tabular}{|l|c|c|c|c|c|c|}
\hline \multicolumn{1}{|c}{$\begin{array}{c}\text { Likert } \\
\text { Scale }\end{array}$} & $\begin{array}{c}\text { Extremely } \\
\text { Low }\end{array}$ & Low & Neutral & High & $\begin{array}{c}\text { Very } \\
\text { High }\end{array}$ & Rank \\
\cline { 2 - 8 } & 1 & 2 & 3 & 4 & 5 & \\
\hline $\begin{array}{l}\text { Performance Indicator } \\
\text { Consumption }\end{array}$ & 1 & 2 & 3 & 41 & 19 & 2 \\
\hline Security & 31 & 32 & 3 & 0 & 0 & 1 \\
\hline Ease of Use & 21 & 37 & 6 & 2 & 0 & 1 \\
\hline Speed of Access & 18 & 41 & 5 & 2 & 0 & 2 \\
\hline $\begin{array}{l}\text { Quality of } \\
\text { Information }\end{array}$ & 30 & 30 & 3 & 3 & 0 & 2 \\
\hline
\end{tabular}

From Table III, the number of respondents in this category that classified the current system as low and extremely low in terms of security, ease of use, speed of access, quality of information and high, very high in time consumption are 63 , $58,59,60$ and 60 respectively which corresponds to category of users $95 \%, 87.9 \%, 89 \%, 90 \%$ and $90 \%$ of the total respondents in this category. Hence, according to this category of users, this satisfies the idea that the current system is weak in these areas.

\section{Net Present Value Analysis}

Year-0 is the investment year for project cost. There is no discount costs for Year-0. The current system's cost and projected benefit are included for three consecutive years (Year-1, Year-2, and Year-3). The discounted rate used is $10 \%$. The Table IV shows the net present value (NPV) analysis for the proposed system.

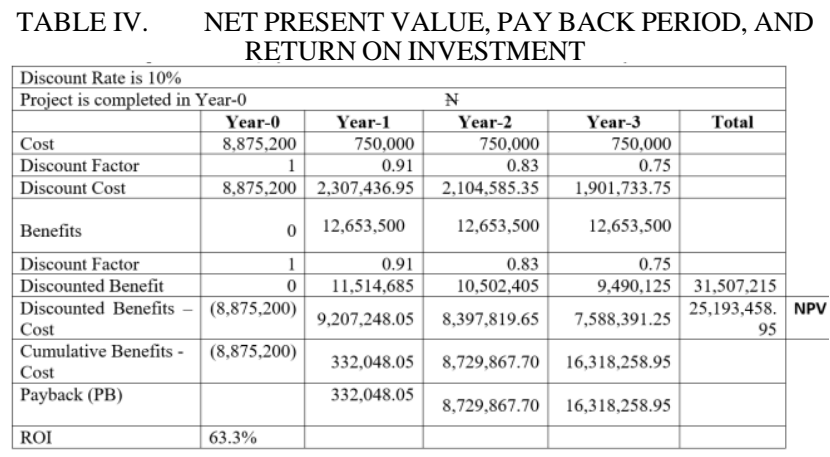

Note: The cost for Year-1, Year-2 and Year-3 respectively in Table IV was gotten by reducing the initial cost $(\mathrm{N} 8,875,200.00)$ by $28.57 \%$.

Decision Rule: The project has a return on investment (ROI) of $63.3 \%$ and a higher, positive and impressive NPV. Therefore, if the project is undertaken, it will yield maximum profit for the universities and as such, it should be considered.

\section{E. The System Database Design}

The name of the database file is "schoolmgt_data.mdf". It was implemented using Microsoft SQL Server - a state-ofthe-art database management system meant for client-server applications. The specifications and design of the database objects are shown below:

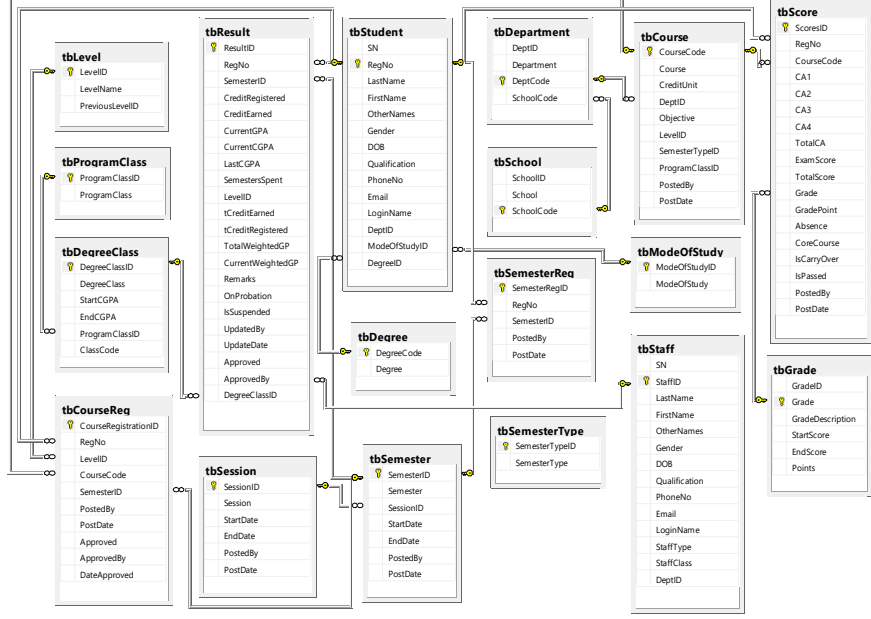

Fig. 1. Database Table Relationship

\section{F. Use Case Diagram of the Proposed System}

Fig. 2 shows a list of actions that defines the interactions between the actors and the result processing and checking system in public universities in Nigeria.

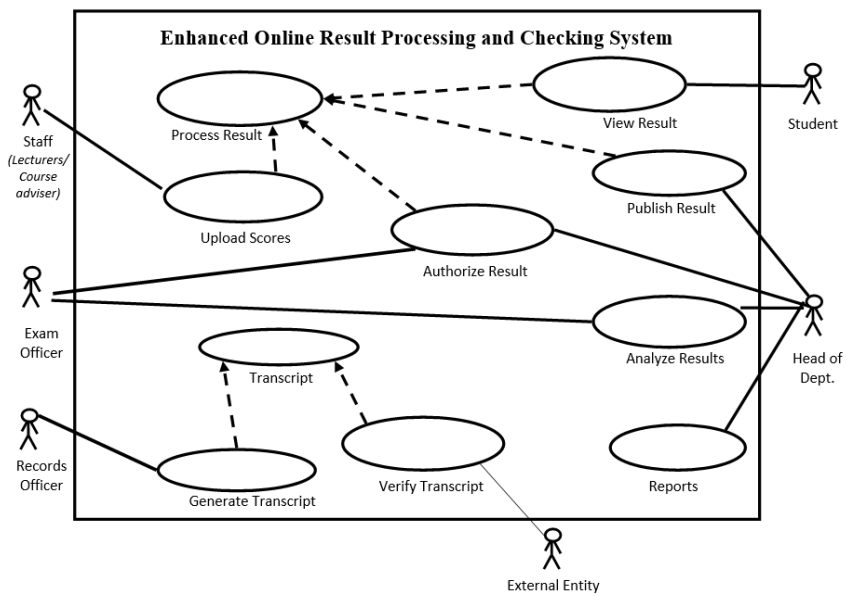

Fig. 2. Use Case Diagram of the New System

\section{G. Level-1 Data Flow Diagram of the Proposed System}

The level-1 data flow diagram in Fig. 3 models the details of the enhanced result processing and checking system. It describes how the system is divided into processes, and how each process handles the data that flows through it.

\section{H. System Architecture of the Proposed System}

Fig. 4 shows the system architecture of the proposed system. This shows the physical tiers where the software runs. That is, the underlying servers (physical or virtual) and server software (web and database servers) that the software will utilize. 


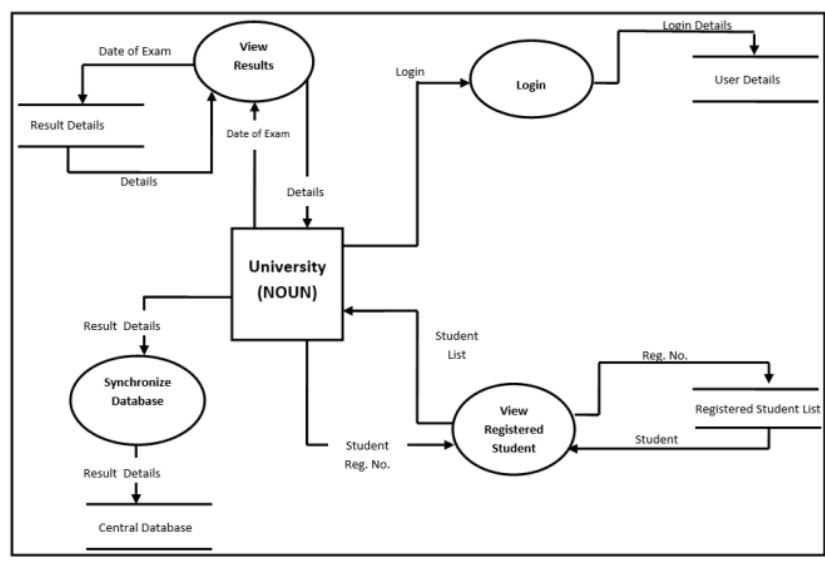

Fig. 3. The Level-1 Diagram of the Proposed System

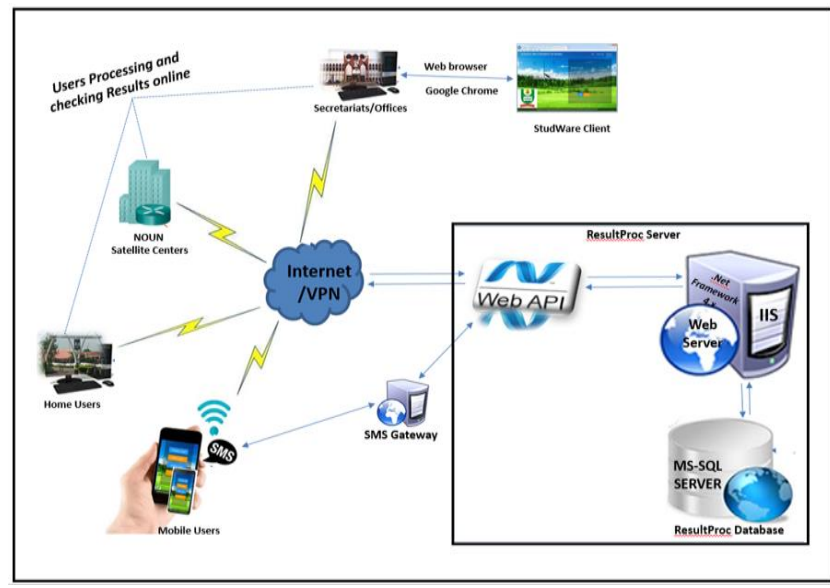

Fig. 4. System Architecture of the Proposed System

\section{Software Architecture of the Proposed System}

Fig. 5 is the software architecture of the proposed system which shows the logical software layers and separation of concerns that were implemented in the proposed system.

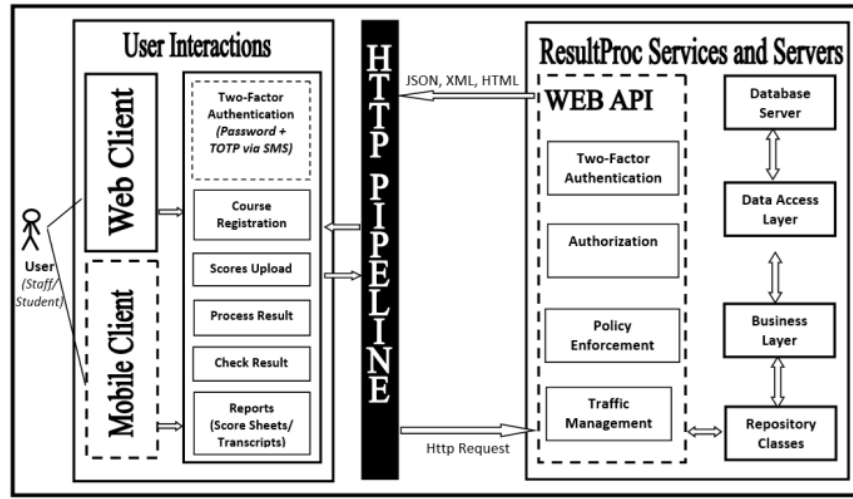

Fig. 5. Software Architecture of the Proposed System

\section{RESULTS AND DISCUSIIONS}

\section{A. System Testing}

The accuracy of the program was tested with some varying data as discussed in this section.

1) Two-factor Authentication (2FA) Testing Student with matriculation number NOU165457231 entered his matriculation number and password as shown in Fig. 6.
When he clicked on Login button, the system confirmed that his username and password were correct. This triggered the generation of TOTP for this user which elapses within four minutes. The short message service (SMS) server routed the generated TOTP to the user's registered phone number and displayed another screen (Fig. 7) for the student to enter the TOTP before proceeding. The SMS service dashboard is shown in Fig. 8. When the student entered the TOTP, the portal finally authenticated him and granted him access to perform student basic operations in the portal.

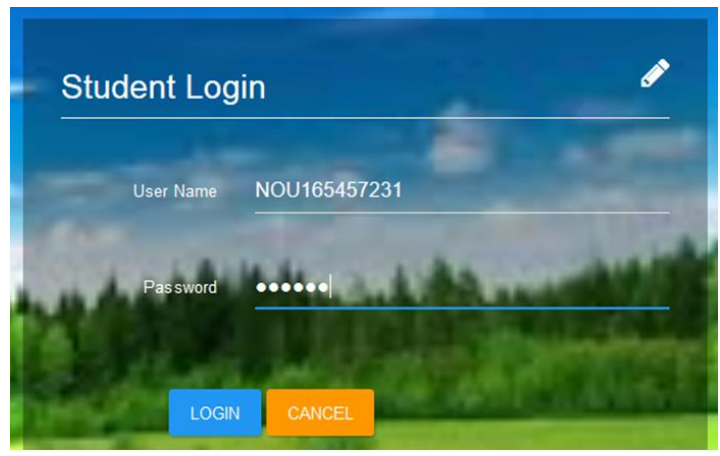

Fig. 6. Student Login Password Authentication Page

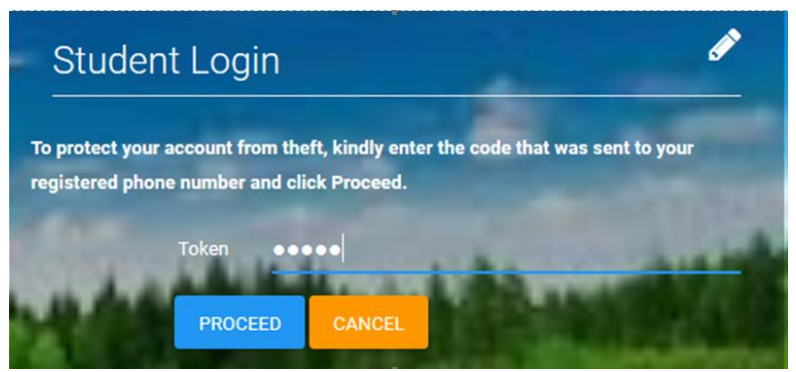

Fig. 7. Student Login Soft Token Authentication Page

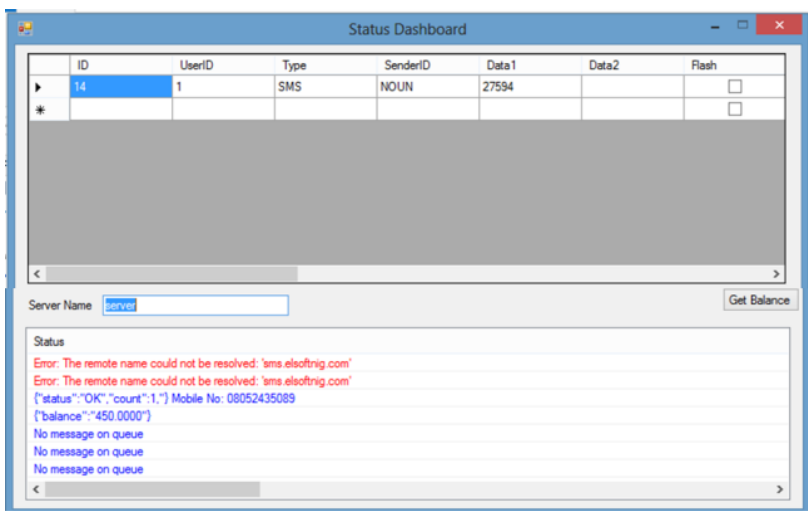

Fig. 8. Showing SMS Server Status Dashboard

2) Testing of Scores Upload and Letter Grading Module Registered students who did their course registration and have scores for their continuous assessment tests and exams were updated as shown in Fig. 9. Student scores were entered in the 'Scores' textbox and 'Save' button was clicked. A success message was displayed indicating that the score was properly updated and a letter grade was displayed in the 'Grade' column showing the newly entered score was correctly graded. 


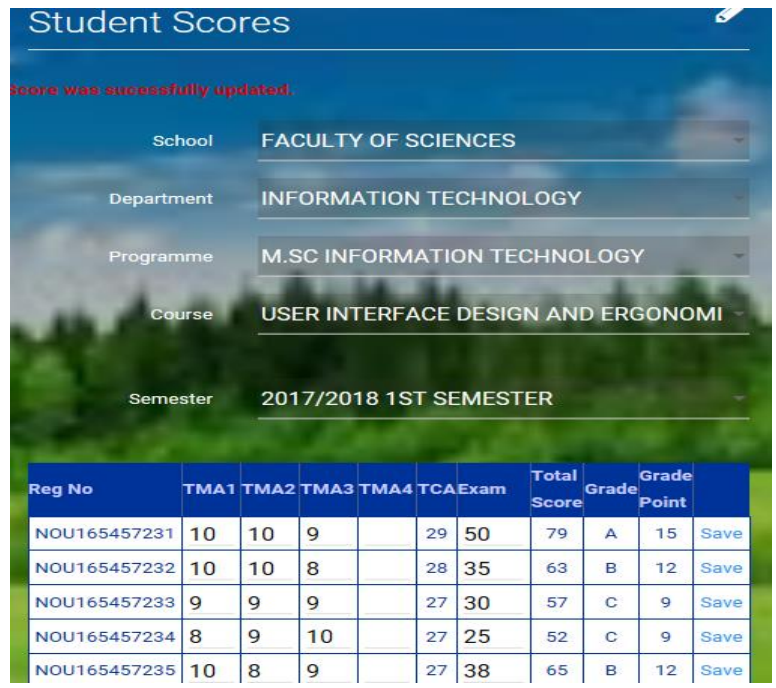

Fig. 9. Student Scores and Letter Grading Testing

\section{B. Assessment/Measurement of the Proposed System}

The new system was evaluated and assessed by the information professionals and Information Consumers based on the performance indicators. With respect to the evaluation and assessment, a third questionnaire was developed. The control matrix of the result from the evaluation is shown in Table V and VI. From Table V, the number of respondents in this category that classified the current system as high and extremely high in terms of security, ease of use, speed of access, quality of information and low, very low in time consumption are $33,34,34,33$ and 1 respectively which corresponds to category of users $92 \%, 93 \%, 93 \%, 92.5 \%$ and $2 \%$ of the total respondents in this category. Hence, according to this category of users, this satisfies the idea that the proposed system has succeeded in overcoming the bottlenecks posed by the existing system

TABLE V. CONTROL MATRIX FOR INFORMATION PROFESSIONALS (EVALUATION OF THE NEW SYSTEM)

\begin{tabular}{|c|c|c|c|c|c|c|c|}
\hline $\begin{array}{c}\text { Likert } \\
\text { Scale }\end{array}$ & $\begin{array}{c}\text { Extremely } \\
\text { Low }\end{array}$ & Low & Neutral & High & $\begin{array}{l}\text { Very } \\
\text { High }\end{array}$ & Rank & Judgment \\
\hline $\begin{array}{l}\text { Performance } \\
\text { Indicator }\end{array}$ & 1 & 2 & 3 & 4 & 5 & & \\
\hline Time Consumption & 35 & 1 & 0 & 0 & 0 & 5 & Strong \\
\hline Security & 0 & 0 & 3 & 5 & 28 & 5 & Strong \\
\hline Ease of Use & 0 & 0 & 2 & 3 & 31 & 5 & Strong \\
\hline Speed of Access & 0 & 0 & 2 & 7 & 27 & 5 & Strong \\
\hline $\begin{array}{l}\text { Quality of } \\
\text { Information }\end{array}$ & 0 & 0 & 2 & 1 & 33 & 5 & Strong \\
\hline
\end{tabular}

From Table VI, the number of respondents in this category that classified the current system as high and extremely high in terms of security, ease of use, speed of access, quality of information and low, very low in time consumption are 34,34 , 36,36 and 0 respectively which corresponds to category of users $93 \%, 93 \%, 100 \%, 100 \%$ and $0 \%$ of the total respondents in this category. Hence, this category of users also confirms that the proposed system addressed the bottlenecks posed by the existing system

\section{TABLE VI. CONTROL MATRIX FOR INFORMATION CONSUMERS (EVALUATION OF THE NEW SYSTEM)}

\begin{tabular}{|c|c|c|c|c|c|c|c|}
\hline \multirow{2}{*}{\begin{tabular}{l}
\multicolumn{1}{c}{$\begin{array}{c}\text { Likert } \\
\text { Scale }\end{array}$} \\
Performance \\
Indicator
\end{tabular}} & $\begin{array}{c}\text { Extremely } \\
\text { Low }\end{array}$ & Low & Neutral & High & $\begin{array}{l}\text { Very } \\
\text { High }\end{array}$ & Rank & Judgment \\
\hline & 1 & 2 & 3 & 4 & 5 & & \\
\hline Time Consumption & 32 & 4 & 0 & 0 & 0 & 5 & Strong \\
\hline Security & 0 & 0 & 2 & 3 & 32 & 5 & Strong \\
\hline Ease of Use & 0 & 0 & 2 & 5 & 29 & 5 & Strong \\
\hline Speed of Access & 0 & 0 & 0 & 12 & 24 & 5 & Strong \\
\hline $\begin{array}{l}\text { Quality of } \\
\text { Information }\end{array}$ & 0 & 0 & 0 & 10 & 26 & 5 & Strong \\
\hline
\end{tabular}

C. Results discussion in the context of research questions.

1) To what extent do the strengths and weaknesses of the existing result processing and checking system affect the quality of information or reports generated?

[3][4][5] in their work pointed out that the information from result processing systems are used to make a multitude of decisions and unless a sufficiently accurate and efficient method is used for the grading, the grades are apt to convey misinformation and lead the decision-maker astray. They argued that only a computerized result processing and checking system can produce reports that can be void of human doctoring, manipulation and errors. [8] insisted that manual systems suffer from higher rate of inaccuracy and that the enormous effect of wrongly computed student results in student academic career and the university as a whole demand that the task be perform meticulously using automated system. From the analysis carried out on the existing system using the Delphi method, it was confirmed that the existing system do not have strengths but rather it does have weaknesses in terms of quality of information generated from it. Its reports must be taken with a pinch of salt.

2) To what extent do the strengths and weaknesses of the existing result processing and checking system affect the time spent in processing students' result?

The observation made after reviewing related literatures in the field of study shows that researchers such as [5] and [6] where able to develop systems that can compute Grade Point Average (GPA) and Cumulative Grade Point Average (CGPA) for each student based on examination scores entered or uploaded. Their system offered some qualities such as reduction in the cost of processing of information and reduction in time spent in computing GPA, preparing students' results and generating transcripts. They emphasized on the importance of high-speed data processing and communication to modern society and economy. This is contrary when it comes to the existing system. The Delphi method-based analysis carried out on the existing system, confirmed that the existing system is weak it comes to speedy processing of students' results. A lot of time that would have been invested in quality research work are been wasted in result computations.

3) To what extent does the security implementations in the existing system of result processing and checking differ from the security mechanisms of the enhanced online result processing and checking system?

[6] and [8] noted that Information is an asset that must be protected. Without adequate network security, many 
individuals, businesses, and governments risk losing their assets. A look at the control matrix for information Professionals and Information Consumers evaluation of the security mechanisms reveals that the existing system is too weak and porous when it comes to security (2\% secured). But the enhanced system is well secured with a rating above $94 \%$. A system that does not have good security control cannot be relied on.

4) To what extent does the existing system as a whole differ from the enhanced online system of result processing and checking?

The observation made after reviewing related literatures in the field of study especially from the researchers [8] [9] and [10] shows that there is a difference between the existing and the enhanced online result processing system. They achieved different results in terms of the performance indicators when evaluated. The existing system has low speed of access, quality of information, security and ease of use. It has high time consumption. In contrast, the enhanced online has very high speed of access, quality of information, security and ease of use, with insignificant consumption when it comes to time. Also, the enhanced online system had a good ROI (63.3\%) and a higher, positive and impressive NPV.

\section{SUMMARY AND CONCLUSION}

The work, enhanced online result processing and checking system in public universities, has looked into various technologies useful in result processing and checking system. The reviewed related works helped in identifying the key performance indicators (KPIs) that makes a result processing and checking system effective and efficient. The KPIs identified include: security, ease of use, speed of access, quality of information and time consumption. Evaluation of the existing system based on the KPIs revealed that the existing system is weak. This led to the proposal and development of an enhanced online result processing and checking system. An evaluation of the new enhanced online system proved that it is more efficient than the existing system. The proposed enhanced online result processing and checking system has higher quality of information (92\%), speed of access $(93 \%)$, secured $(91 \%)$, ease of use $(92.5 \%)$ and low consumption of time $(2 \%)$. The financial analysis yielded a positive NPV and a very impressive ROI.

The identified KPIs have important roles to play in the determination of effective and efficient result processing and checking system. The proposed system which captures all the performance indicators outlined in this work should be adopted by public universities in developing countries especially Nigeria for effective and efficient result processing and checking.

\section{REFERENCES}

[1] Mike S., Laura N., Peter L. and Giasemi V. (2008). "Literature review in mobile technologies and learning". Future Lab Series Report 11, submitted to the University of Birmingham, pp 1-48. ISBN: 09548594-1-3.

[2] Bala E. and Ezenma A. and Nyap C. (2014). "Design and implementation of result processing system for public secondary schools in nigeria". IJCIT, Vol. 3, No. 1, 2279-6764

[3] Erinma A. (2008). "Design and implementation of a web-based university admission and placement neural network model". Open Access Institutional Repository Ahmadu Bellow University, Zaria, p 7.

[4] Ukem E. and Ofoegbu F. (2012): A software application for university students results processing. Journal of Theoretical and Applied Information Technology, Vol. 35, No. 1, p 34

[5] Dada O., Raji A., Oyedepo F., Yusuf I., and Saka T. (2017). "Design and implementation of an integrated result processing system in a networked environment". British Standards Institution, Vol. 2, No. 5, pp 131-137.

[6] Ise, O. (2015). "A novel framework for student result computation as a cloud computing service". American Journal of Systems and Software, Vol. 3, No. 1, pp 13-19.

[7] Bernice B. (1968): Delphi Process: "A Methodology Used for the Elicitation of Opinions of Experts". RAND, 3925, p15. Retrieved on Oct 15th 2017 from https://en.wikipedia.org/wiki/Delphi_method

[8] Padakuu (2017): "Difference Between Manual and Automated System, Manual System vs Automated System”. Padakuu online study center. $\begin{array}{lllll}\text { Retrieved on } & \text { October } & 15 \text { th } & 2017 & \text { from }\end{array}$ http://www.padakuu.com/article/1-difference-between-manual-andautomated-system-manual-system-vs-automated-system

[9] Shubham P. (2016). "Data processing cycle, Stages of Data Processing Planning Tank". Retrieved on October 15th 2017 from https://planningtank.com/computer-applications/data-processing-cycle data processing cycle / with stages, diagram and flowchart

[10] Rudo P. (2013): "Important stages in the data processing cycle". Retrieved on Oct 15th 2017 from http://www.enterprisefeatures.com/6 important-stages-in-the-data-processing-cycle/ 